\title{
The Maastricht inflation criterion: How unpleasant is purgatory?
}

\author{
Aleš Bulîr ${ }^{\mathrm{a}, *}$, Jaromír Hurník ${ }^{\mathrm{b}}$ \\ ${ }^{a}$ International Monetary Fund, Washington, DC, USA \\ ${ }^{\mathrm{b}}$ Czech National Bank, Prague, Czech Republic
}

Received 19 January 2006; received in revised form 1 June 2006; accepted 17 July 2006

\begin{abstract}
The Maastricht inflation criterion, designed in the early 1990s to bring "high-inflation" EU countries in line with "low-inflation" countries prior to the introduction of the euro, poses challenges for both new EU member countries and the European Central Bank. While the criterion has positively influenced the public stance toward low inflation, it has biased the choice of the disinflation strategy toward short-run, fiat measures - rather than adopting structural reforms with longer-term benefits - with unpleasant consequences for the efficiency of the eurozone transmission mechanism. The criterion is also unnecessarily tight for new member countries as it mainly reflects cyclical developments.

(C) 2006 Elsevier B.V. All rights reserved.
\end{abstract}

JEL classification : E31; E32; E42; F33

Keywords: ERM2; Maastricht inflation criterion; New EU member countries

"And I shall sing about that second realm where man's soul goes to purify itself and become worthy to ascend to Heaven." Dante; The Divine Comedy, Purgatorio, Canto I

\section{Introduction}

The Maastricht inflation criterion - inflation of no more than $1.5 \%$ above the average inflation rate of the three European Union (EU) member states with the most stable prices - was designed in the early 1990s to bring such "high-inflation" countries as Italy and the United Kingdom in

* Corresponding author. Tel.: +1 202623 7145; fax: +1 2025897145 .

E-mail address: abulir@imf.org (A. Bulîr). 
line with such "low-inflation" countries as Germany and the Netherlands prior to the introduction of the euro. While the inflation criterion motivated all-European inflation convergence in the late 1990s, it did not prevent acceleration of inflation in several countries after their entry into the eurozone. What can the new EU member countries (NMCs) do to minimize the compliance cost of this criterion? ${ }^{1}$

Assessments of the Maastricht inflation criterion - by the European Union (European Commission, 2004), IMF (Schadler et al., 2005), national central banks (Bárta, 2006), and this study - point to modest costs associated with the criterion, which are promised to be further ameliorated by the "flexibility" of the European Central Bank (ECB) in dealing with new member countries. The "temporal punishment" for past inflation sins seems low, especially since history has shown that the criterion can be fulfilled with a healthy dose of administrative measures. There are, however, differences between the 1990s and 2000s.

Unlike the old EU member countries, which were mimicking the then "engine of Europe," Germany, and the most credible central bank, the NMCs are asked to match the performance of three countries that have in common only that they are in the downturn phase of their business cycles. A tight 1-year inflation criterion may motivate the authorities to pursue fiat disinflation policies of short-term demand stabilization and government intervention at the expense of long-term structural reforms that would create a low-inflation environment (Ozkan et al., 2004). For example, a country may opt for a temporary wage freeze as opposed to liberalizing its labor market. A part of the increase in the price level may result from productivity differentials in the tradable and nontradable good sectors (the Balassa-Samuelson effect) and thus be largely insensitive to macroeconomic and structural policies. The resulting monetary transmission distortions and inefficiencies are likely to increase the cost of future disinflations and complicate ECB policymaking for years to come.

The contribution of the paper is to link pre-euro disinflation strategies with costs of future disinflations in nine calibrated country models. Drawing on the experience of EU-15, the results suggest that in countries that choose the fiat disinflation strategy of "low inflation now, reforms later" have modest short-term costs of disinflation, mostly attributable to "borrowed credibility" from the ECB. But their long-term costs are high, reflecting structural rigidities inherited from the past. In contrast, reformist countries benefit from flexible markets and forward-looking agents, both of which push disinflation costs down. Thus, the new member countries would benefit from a criterion that makes the choice of a fiat disinflation strategy less likely, either by calculating the criterion over the business cycle or by lengthening the evaluation period.

This paper is organized as follows. First, we link EU inflation developments with inflation drivers. Second, we discuss the nexus between structural reforms and the monetary transmission mechanism in the EU. Third, we formulate a simple model, calibrate it for nine EU countries, and compute hypothetical output losses from disinflation policies. Finally, we discuss the policy implications of the Maastricht criterion for the conduct of monetary policy in the NMCs and by the ECB.

\footnotetext{
${ }^{1}$ The "old" member countries (EU-15) are Austria, Belgium, Denmark, Finland, France, Germany, Greece, Ireland, Italy, Luxembourg, the Netherlands, Portugal, Spain, Sweden, and the United Kingdom. The new member countries are the Czech Republic, Cyprus, Estonia, Hungary, Latvia, Lithuania, Malta, Poland, and Slovakia, Slovenia.
} 


\section{Inflation in the European Union}

The concept of the new European monetary order was simple. Once exchange rates are stabilized and inflation rates converge, the former would be irrevocably fixed and the latter would be controlled by pan-European monetary policy executed by the ECB. This plan worked reasonably well in the 1980s and 1990s, and inflation remained close to the target "of close to but below 2\%" during the early 2000s. The Maastricht criterion failed, however, to close the differential between high- and low-inflation countries.

\subsection{The role of the Maastricht inflation criterion}

The European Monetary Union (EMU) was set up as an institutional arrangement to foster low inflation. Developments in the 1970s showed that time-inconsistent policies fueled by distorted labor markets, tax systems prone to inflation bias, and other structural impediments make it difficult to ensure a low-inflation environment in Europe. Thus, the EU imposed various entry criteria for the EMU - such as the Maastricht inflation criterion - to encourage the EU countries to undertake fundamental economic reforms prior to joining the EMU (see Bulîr and Hurník (2006) for additional details). Indeed, the inflation differential between low-inflation and highinflation countries, which was in double digits from the mid-1970s to the early 1980s, started to narrow in the early 1990 s, declining to $2-3 \%$ points by 1997 (Fig. 1).

The Maastricht inflation criterion did motivate all-European inflation convergence, but the disinflation process was also facilitated by the secular decline in inflation. While the empirical literature is not entirely conclusive regarding the contribution of the criterion, it demonstrates that the criterion changed the preferences of the monetary authorities. ${ }^{2}$ For example, it has been shown that the coefficient of policy aversion to inflation has increased (Cecchetti and Ehrmann, 1999; Arestis and Mouratidis, 2004). The literature finds, however, a weak positive impact of structural reforms in the eurozone on the area's inflation, mainly because of slow and insufficient reforms (OECD, 2002; Ahearne and Pisani-Ferry, 2006).

\subsection{The Maastricht inflation criterion: sinners and saints}

The Maastricht inflation criterion is monitored and assessed only prior to the adoption of the euro, and each country is required to exhibit "saintly" inflation for at least 1 year. The obvious question is then whether the Maastricht inflation criterion (and the EMU in general) has succeeded in permanently lowering inflation. Have all the sins been purged?

Following the euro's adoption, inflation in the three highest-inflation eurozone countries averaged $1 \%$ point higher than what was required by the criterion specified for the member countries of the European exchange rate mechanism (ERM2). On average, one in five EU-15 countries has recorded inflation at least 50 basis points above the Maastricht criterion. While this is far from the double-digit differentials seen in the 1970s and 1980s, under a fixed exchange rate regime such inflation still implies a long-term loss of price competitiveness unless it is compensated for by productivity growth. Inflation developments in the NMCs have varied and several countries have yet to converge to the level of the criterion (Latvia and Slovakia). The three highest-inflation NMCs

\footnotetext{
${ }^{2}$ Some useful, if incomplete, reviews of the inflation convergence literature are those of Bini Smaghi (1994) and Camarero et al. (2000).
} 

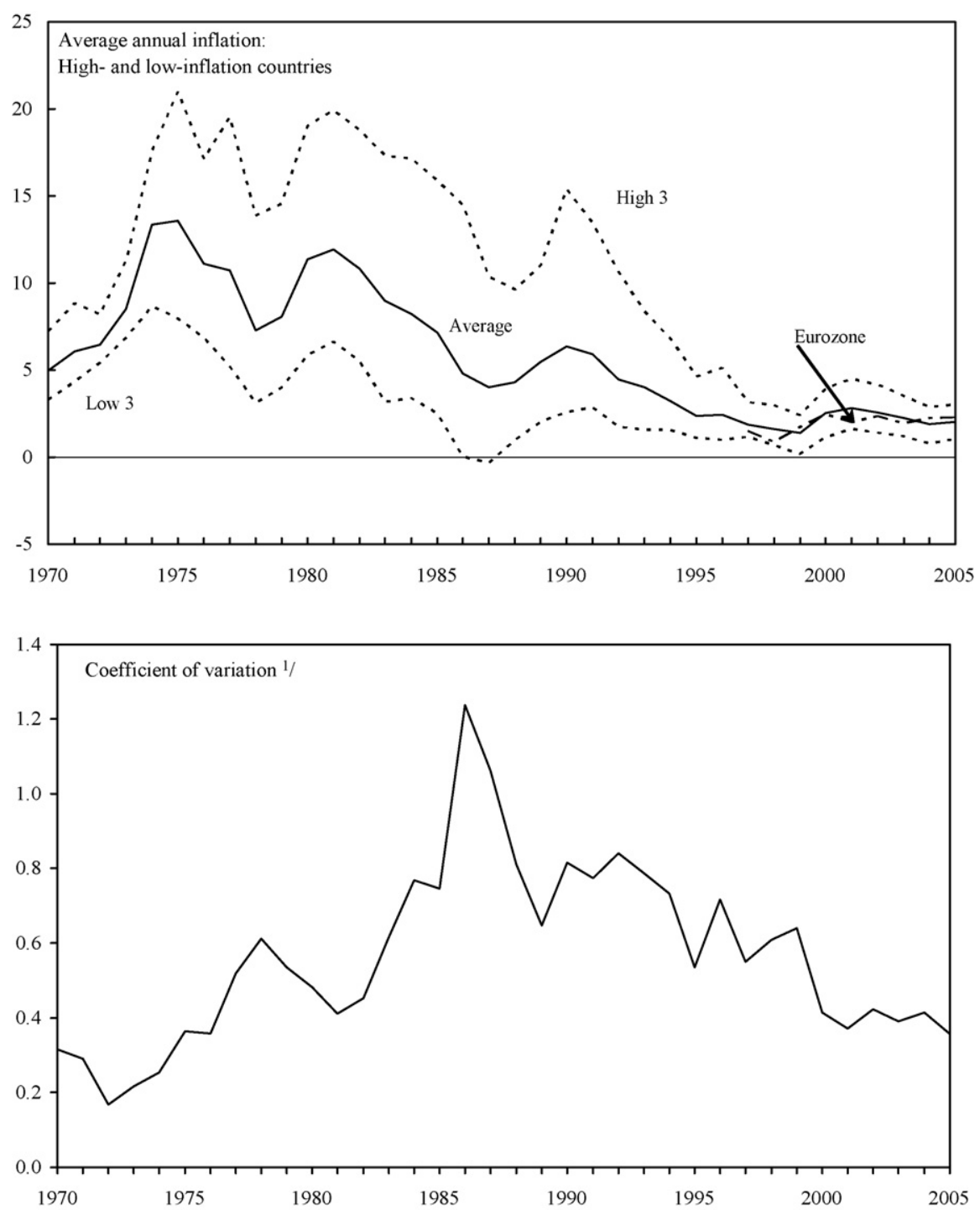

Fig. 1. EU-15: inflation developments, 1970-2005 (EU-15 comprises Austria, Belgium, Denmark, Finland, France, Germany, Greece, Ireland, Italy, Luxembourg, The Netherlands, Portugal, Spain, Sweden, and the United Kingdom. The eurozone excludes Denmark, Sweden, and the United Kingdom) (annual inflation rate, in \%). 'Sample standard deviation/ sample mean. Source. World Economic Outlook and author's calculations.

have been missing the inflation criterion on average by $3.5 \%$ points. Technically, of course, neither the eurozone countries nor the NMCs were bound by the criterion. It is the ECB that is responsible for inflation in the eurozone and none of the NMCs had to meet the criterion as they were not seeking to adopt the euro in 2005 or 2006, although Slovenia will enter the eurozone in January 2007.

Which countries are the most frequent sinners, with inflation above the level implied by the Maastricht criterion? In the EU-15 group, Greece, Ireland, and Spain have had higher inflation, while among the NMCs the list includes Estonia, Hungary, Latvia, Slovakia, and Slovenia. Six of 
Table 1

EU inflation saints ${ }^{\mathrm{a}}$ (number of quarters with inflation equal or below the reference inflation rate) ${ }^{\mathrm{b}}$

\begin{tabular}{lcccc}
\hline & $1999-2005$ & & $2004-2005$ & \\
\cline { 2 - 4 } & Quarters (28) & Ouput gap $^{c}$ & & Quarters (8) \\
\hline EU-15 & & & & Ouput gap $^{c}$ \\
Belgium & 4 & Yes & 0 & Yes \\
Denmark & 5 & Yes & 5 & Yes \\
Germany & 18 & Yes & 1 & Yes \\
France & 8 & No & 0 & Yes \\
Luxembourg & 2 & Yes & 0 & Yes \\
Netherlands & 1 & Yes & 1 & Yes \\
Austria & 7 & Yes & 1 & Yes \\
Finland & 9 & Yes & 8 & Yes \\
Sweden & 15 & Yes & 5 & Yes \\
United Kingdom & 14 & No & 0 & No \\
NMC-10 & & & & Yes \\
Czech Republic & 6 & Yes & 2 & Yes \\
Estonia & 1 & Yes & 1 & No \\
Lithuania & 16 & No & 2 & Yes \\
Poland & 4 & Yes & 1 & \\
\hline
\end{tabular}

Source. Eurostat, AMECO and authors' calculations.

a The following countries' inflation was not below the reference inflation during these periods: Greece, Spain, Ireland, Italy, Netherlands, Portugal, Estonia, Latvia, Hungary, Malta, Slovenia, and Slovakia.

b The official "Maastricht" definition.

${ }^{\mathrm{c}}$ Estimated negative output gap; potential GDP is calculated from a Cobb-Douglas produc includes labor, capital, and trend total factor productivity.

the EU-15 countries have had inflation above the Maastricht criterion at some point during 20012005, each of them for at least one quarter. ${ }^{3}$ In contrast, every NMC substantially exceeded the criterion, although Lithuania and Malta did so only briefly.

The saints - that is, the countries that have comprised the base for calculating the Maastricht criterion - are not particularly happy campers either, as these countries experienced substantial negative output gaps (Table 1). ${ }^{4}$ Low inflation has come at a cost of GDP below its potential as the economies move along a short-run Phillips curve. The composition of the saints group changesonly five countries did not make it into the group for at least one quarter (Greece, Ireland, Italy, Spain, and Portugal). Four of the NMCs were temporarily a part of the reference group, typically also experiencing negative output gaps.

\subsection{Why is inflation in some EU countries higher than in others?}

Against the background of a stable average inflation rate in the EU-15 countries, inflation accelerated in several, mostly high-growth, economies. The dispersion of European inflation

\footnotetext{
${ }^{3}$ Potential output is estimated by the European Commission staff from a Cobb-Douglas production function estimate with trend total factor productivity (http://ec.europa.eu/economy_finance/indicators/annual_macro_economic_database/ ameco_en.htm).

${ }^{4}$ The following countries' inflation was not above the Maastricht criterion during these periods: Belgium, Denmark, Germany, France, Italy, Austria, Finland, Sweden, and United Kingdom.
} 
drifted upward after the drive toward the euro pushed it downward sharply in the late 1990s and early 2000s. The differential between the three countries with the highest and lowest inflation rates fell from about $4 \%$ to less than $2 \%$ by 1997 , only to stabilize between $2.5 \%$ and $3 \%$ thereafter.

The dispersion of inflation rates across member countries has introduced noise into the ECB policymaking process to the extent that the EU-wide inflation rate reflects an average of national inflation rates and may not reflect cyclical conditions in any given country. It seems clear that a low level of average inflation in the eurozone over time would not necessarily translate into a low level of volatility across countries (Angeloni and Ehrmann, 2004; Hofmann and Remsperger, 2005). It could be argued that regional price volatility is irrelevant for stabilization policy in an optimal currency area, but the eurozone is not an optimal currency zone and is unlikely to become one soon (Babetskii et al., 2004; Schadler et al., 2005). Europe lacks nonmonetary equilibrating mechanisms, such as the capital and labor mobility that are found in optimal currency areas, and a greater reliance on relative price and wage changes among countries is needed. Countries with persistently high inflation are likely to lose price competitiveness unless higher prices are compensated by productivity growth. Developments in some eurozone countries - such as Italy or Portugal - seem to fit the pattern of competitiveness losses (Bulîr and Šmídková, 2005).

Several explanations for the inflation differentials have been put forward, namely, price-level convergence, demand pressures, and "structural" distortions, and these explanations are relevant empirically (Fig. 2). In Bulîr and Hurník (2006) we review these explanations in more detail and estimate the impact of these factors in a two-step generalized method of moments (GMM) panel regression, finding that EU-15 inflation during 1996-2005 has been associated mostly with the variability of the output gap and structural reform variables, while the price-level convergence variable has not been statistically significant. Quantitatively, the output gap of $1 \%$ has been associated with a reduction in annual inflation of about $0.3-0.4 \%$. More regulation in product or labor markets by one sample standard deviation has been associated with a rise in inflation, by $0.3-1.0 \%$.

Empirical literature for the EU-15 countries failed to find strong support for the BalassaSamuelson effect. ${ }^{5,6}$ Alberola-Ila and Tyrväinen (1998) found that tradable-to-nontradable productivity differentials are substantially smaller than those implied by the Balassa-Samuelson effect as nontradables' productivity growth has been much faster than thought earlier. As long as the productivity growth differentials remain small in the NMCs - as suggested by Égert et al. (2005) or Flek et al. (2003) - the Balassa-Samuelson effect is unlikely to explain fully either inflation or exchange rate appreciation. At the same time, however, a gradual change in the relative prices of nontradable goods has been observed in most NMCs. Thus, despite the fact that these relative-price changes cannot be linked directly to the productivity differentials, central bank forecasting models typically include trend variables to capture persistent real exchange rate appreciation.

The experience of the old member countries provides valuable lessons for new members. Apart from the relatively high sacrifice ratio, the impact of past reforms (or a lack thereof) drives

\footnotetext{
${ }^{5}$ The Balassa-Samuelson effect is expected to work as follows. Productivity growth in the tradable good sector is assumed to exceed that in the nontradable good sector. Assuming further that wages equalize across sectors, faster tradables' productivity growth pushes up wages in all sectors, thus leading to an increase in the relative prices of nontradables. With a fixed exchange rate, the relative-price increase in fast catching-up countries may result in an overall price level increase relative to slow-growing countries.

${ }^{6}$ For associated measurement problems see Čihák and Holub (2005).
} 

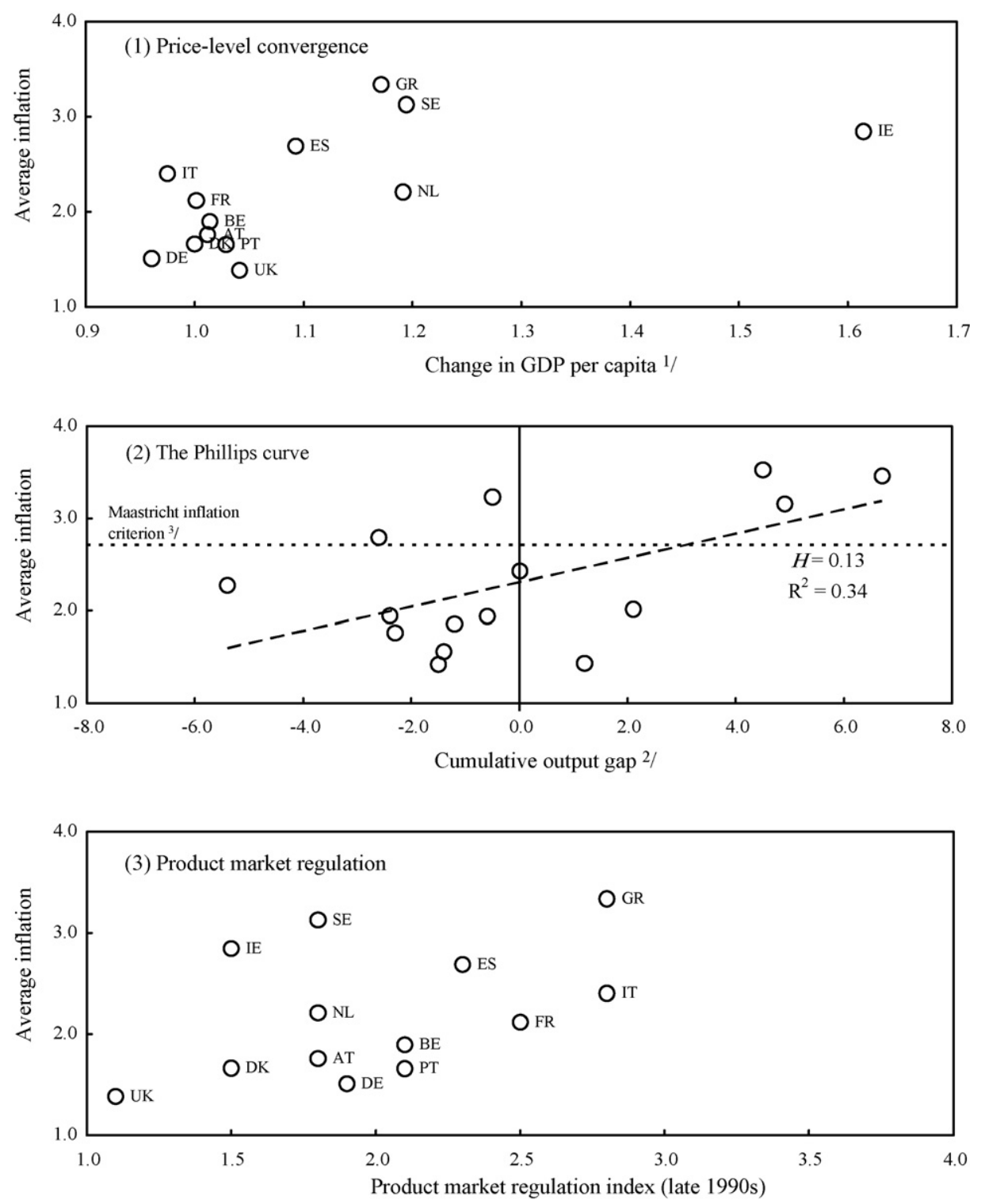

Fig. 2. EU-15: three factors of inflation, 2001-2005. ${ }^{1}$ Change in GDP per capita in PPP terms, between 2005 and 1996 , relative to Denmark. ${ }^{2}$ Output gap $=$ actual GDP - potential GDP. Potential GDP is calculated from a Cobb-Douglas production function that includes labor, capital, and trend total factor productivity. ${ }^{3}$ Implied average value for 2001-2005. Source. AMECO, World Development Indicators, World Economic Outlook, Conway et al. (2005), and author's calculations.

inflation in the EU-15 countries. The lack of structural reforms may push inflation up in the future through two channels: first, through cost-push channels, as a result of either markup or wage-cost pressures; and, second, through its impact on the monetary transmission mechanism, by making inflation more persistent. Moreover, the Balassa-Samuelson effect may become stronger in the future. 


\subsection{Taking stock of the authorities' disinflation choice: minimizing purgatory pains}

At the onset of disinflation, the national authorities assess the available disinflation tools and their choice of which to use will matter for long-term inflation. The rate of inflation can be brought down either permanently by credible monetary policy and market-oriented reforms; temporarily by short-term, fiat measures; or by a combination of both. With regard to permanently reducing inflation, the authorities establish a low-inflation environment by consistently pursuing price stability and gradually embedding low-inflation expectations. As for temporarily reducing inflation, the authorities bring about ad hoc changes in regulated prices and indirect taxes, engineer sharp demand contractions to bring inflation down along a short-run Phillips curve, or forge a temporary consensus of price and wage moderation. ${ }^{7}$

In the late 1990s, the authorities in eurozone member countries demonstrated the possibility of manipulating the consumer price index through changes in regulated prices and indirect taxation and measures in factor markets. For example, the Irish government was advised to "reduce the headline rate of inflation by reducing indirect taxes" (Beggs, 2000). Virtually all EU-15 countries engaged in some sort of fiscal or accounting gimmickry in their rush to the euro (Koen and van den Noord, 2005; Ahearne and Pisani-Ferry, 2006). The output cost of pre-euro demand contractions were justified by their temporary nature as compared to the permanent benefits of eurozone membership.

The optimal choice of disinflation tools depends of the cost of reforms and benefits of eurozone membership, conditional on meeting the inflation target. If the country puts enough weight on the benefits of membership, the authorities choose the fiat measures in order to enter as quickly as possible with maximum political support (Ozkan et al., 2004). In contrast, the disinflation strategy of long-term structural reforms can be protracted, possibly pushing the date of eurozone membership too far off. If, however, the country assigns less weight to the immediate benefits of the euro, then the authorities are likely to deliver low inflation by additional structural reform measures and fewer fiat measures. The country would then enter the eurozone at a later date, but presumably with a healthier economy.

The choice of disinflation strategies also depends on whether the criterion is "tight" or "soft." A tight criterion will push the authorities toward fiat measures as the chance of meeting such a target would be limited without aggressive steps. In contrast, a soft criterion should, other things being equal, push the authorities toward adopting reform measures as the chance of meeting a soft target would be sufficiently high without fiat actions or gimmicks.

Post-euro developments suggest that the initial choice of the reform-or-fiat disinflation mix has had long-term consequences. Structural rigidities, solidified by the use of administrative measures in the run-up to the euro, translate into a flatter Phillips curve, making the monetary policy transmission mechanism less efficient and future disinflations more costly. While the fiatmeasure strategy may appear optimal over the short term, the longer-term outcome may be quite different. The failure to create a low-inflation environment is likely to push the rate of inflation up over time, calling for further rounds of fiat-measure disinflation. ${ }^{8}$

\footnotetext{
${ }^{7}$ Some of the new member central banks have resigned themselves to the need for tight demand policies in the run-up to the euro: for example, the Slovak National Bank (2005) in its inflation forecast for 2007-2008, announced that "monetary conditions should, however, throughout the period remain moderately restrictive so as to avoid the complete closing of the output gap."

${ }^{8}$ For example, in March 2006 the European Trade Union Confederation has recommended "a moratorium on indirect taxes and administrative prices" to keep inflation below 2\% (European Trade Union Confederation, 2006).
} 


\section{How costly can disinflation be and why?}

We now build on the above link between structural reforms and the monetary transmission mechanism to simulate the cost of disinflation policies. To this end, we build a simple countryspecific model based on Walsh (2003), asking two questions ${ }^{9}$ :

(1) "What output gap - resulting from a monetary policy action - would have been consistent with bringing inflation toward the Maastricht criterion?" This is a hypothetical question because (i) some of the countries in our sample are already eurozone members and the Maastricht criterion does not apply to them; (ii) the eurozone members do not have control over monetary policy; and (iii) the NMCs did not (or could not) enter the eurozone at the time point we selected for our simulations. The disinflation announcements in the eurozone countries can be thought of either as the ECB targeting the same disinflation for all countries or as the country leaving the eurozone and regaining monetary independence.

(2) What is the magnitude of the sacrifice ratio for a uniform disinflation shock of 100 basis points? Although the exact numerical results of our simulations need not be taken literally, the identical model structure enables us to evaluate the long-term costs of disinflation across individual countries and link these costs to past disinflation strategies.

\subsection{The model}

The model consists of five equations that represent aggregate demand, aggregate supply, the uncovered interest rate parity condition, term structure, and the policy-reaction function (see Appendix A for further details). The aggregate spending relationship corresponds to the open economy version of the traditional IS curve and takes the form:

$$
y_{t}=a_{1} y_{t-1}-a_{2} r_{t-1}+a_{3} q_{t-1}+\mu_{t},
$$

where $y, r$, and $q$ are the deviations of log output, the long-term real interest rate, and the real exchange rate from their steady-state level, respectively; and $\mu$ is an aggregate demand shock. While we do not know the underlying steady-state levels, it is sufficient for our approach to assume that they are mutually consistent. Whereas the coefficient $a_{1}$ captures the persistence of output behavior, the coefficients $a_{2}$ and $a_{3}$ reflect the impact of the real interest and exchange rates, respectively, on economic activity.

The aggregate supply equation, the Phillips curve, is as follows:

$$
\pi_{t}=b_{1}\left(b_{2} \pi_{t-1}+\left(1-b_{2}\right) E_{t} \pi_{t+1}\right)+\left(1-b_{1}\right) \pi_{t-1}^{\mathrm{imp}}+\gamma y_{t-1}+\eta_{t}
$$

where $\pi$ is the quarterly change of the price level, $E \pi$ denotes inflation expectations, $\pi^{\text {imp }}$ import price inflation (a sum of foreign inflation and the change of the nominal exchange rate), and $\eta$ is an aggregate supply shock. Inflation is persistent and can decline either through the impact of expectations $\left(b_{2}\right)$, a negative output gap $(\gamma)$, or positive external shocks. The supply relationship encompasses multi-period, overlapping nominal contracts, extended beyond a direct impact of import prices. The latter is an important feature of small open economies that rely heavily on the exchange rate channel of monetary transmission (the exchange rate pass-through effect), with the coefficient $\left(1-b_{1}\right)$ approximating the weight of imported goods in the consumer basket.

\footnotetext{
${ }^{9}$ Walsh drew on a variety of models, both for the closed economy case (Fuhrer and Moore, 1995a,b; Fuhrer, 1997; Rotemberg and Woodford, 1997) and the open-economy case (Batini and Haldane, 1999; Svensson, 2000).
} 
Agents may not be fully forward-looking and may base their inflation expectations both on history and currently available information:

$$
E_{t} \pi_{t+1}=e_{1} \pi_{t+1}^{e}+\left(1-e_{1}\right) \pi_{t-1},
$$

where $\pi_{t+1}^{e}$ represents model-consistent expectations. Expectations for all agents in the economy are "rational," but this does not prevent some of the agents from using the rule of thumb and looking at past inflation as well.

The relationship with the world is captured through the uncovered interest rate parity condition that relates the behavior of domestic and foreign interest rates and the nominal exchange rate, while exhibiting some persistence:

$$
\Delta s_{t+1}=c_{1} \Delta s_{t}+\left(1-c_{1}\right)\left(i r_{t}-i r_{t}^{*}-\operatorname{prem}_{t}\right)+v_{t},
$$

where $\Delta s$ is the change in the nominal exchange rate, $i r$ and $i r^{*}$ the domestic and foreign longterm nominal interest rates, respectively, prem the risk premium, and $v$ is an exchange rate shock. The coefficient $c_{1}$ determines the level of exchange rate persistence-higher values imply less sensitivity to interest rate changes. The long-term rate is approximated by the 1-year nominal interest rate, while the short-term nominal interest rate is represented by the 3-month nominal interest rate that is directly linked to the policy reaction function. Looking forward, the long-term rate follows the term structure equation as a simple average of short-term interest rates.

The model is closed by a policy reaction function, the Taylor rule. The monetary authority responds to the level of expected inflation; the deviations of expected inflation from a target, $\pi^{\mathrm{T}}$; and the output gap, while taking into account the previous-period policy stance, $i_{t-1}$ :

$$
i_{t}=d_{1} i_{t-1}+\left(1-d_{1}\right)\left(\pi_{t+1}^{e}+d_{2}\left(\pi_{t+1}^{e}-\pi^{\mathrm{T}}\right)+d_{3} y_{t}\right)+\varepsilon_{t},
$$

where $i$ is the domestic short-term nominal interest rate and $\varepsilon$ is a policy shock. The monetary authority is fully forward-looking and thus uses model-consistent inflation expectations, $\pi_{t+1}^{e}$, in its decisions.

The disinflation path is determined jointly by all elements of the model. Other things being equal, disinflation requires an output gap and the inflation sensitivity to the output gap is determined by the slope of the Phillips curve, $\gamma$. However, disinflation is less painful if the agents are forward-looking (a small $b_{2}$ coefficient), or the exchange rate is less persistent (a small $c_{1}$ coefficient), or both. To ensure comparability of individual countries, we assume that the weights of inflation and output stabilization $-d_{2}$ and $d_{3}$, respectively - in the policy reaction function are the same for all countries and equal to 0.5 (Taylor, 1993), while the policy persistence parameter, $d_{1}$, is country-specific.

\subsection{Calibration}

The choice of countries is based on their inflation history. We simulate disinflations in four EU-15 countries with historically high inflation rates: Greece, Ireland, Italy, and Spain; and in five NMCs: the Czech Republic, Hungary, Poland, Slovakia, and Slovenia. The country-specific models are calibrated following the methodology outlined in Coats et al. (2003) and Berg et al. (2006). The parameters are based on: (i) economic principles; (ii) available econometric and anecdotal evidence; and (iii) the sensible behavior of the whole model. The calibration process is iterative: choosing reasonable parameter values, examining the properties of the model next, and changing the parameter values or the structure of the model, until the model behaves 
appropriately. Thus the model is assessed by its ability to replicate observed behavior rather than a purely statistical calculation.

First, we replicate the structural-model Phillips curve estimates summarized in Rumler (2005) and other recent national central bank, ECB, and IMF publications (for a list of references see Bulîr and Hurník, 2006). Second, we set the remaining parameters to mimic the known features of the individual economies, drawing either on the impulse response functions from the published central banks models or structural VARs. Both help to assess the underlying dynamics in countries under consideration. Although the estimates of impulse response functions in the NMCs should be taken with a grain of salt, they are useful for designing the dynamic properties of individual calibrations. They help us to replicate, for example, the strong exchange rate channel in Hungary, stability of the real exchange rate in Slovenia, or a "two-peak" response of inflation to an interest rate shock reported in Poland. The coefficients exemplify the impact of past policy choices. Reform laggards tend to have a flatter Phillips curve (Hungary, Italy), while countries with credible monetary policies benefit from the forward-looking behavior of economic agents (the Czech Republic, Ireland). We report the main country-specific coefficients in Table 2 and in more detail in Appendix A.

Below we summarize the salient features of the simulated economies that we reflected in our calibrations. The old member states differ substantially in the observed persistence of their economies and in expectations formation. Greece is a low-persistency economy with respect to IS and Phillips curves persistency. The financial markets are, however, mostly backward-looking, with persistent exchange rates. Ireland's monetary policy reacts quickly and forcefully, mostly through the exchange rate channel. Although output is not much affected by monetary policy shocks, the gap-to-inflation nexus is comparatively strong. Italy appears to have a highly persistent economy with a flat Phillips curve. This persistence is compensated only partly by reactive monetary policy (low persistence in policy rates). Spain seems to be a highly persistent economy, but the Phillips curve is steeper than that of Italy.

The NMCs exhibit comparable persistence of their real economies and inflation, but they differ in the slope of their Phillips curves (i.e., monetary policy credibility), and in the forwardlooking behavior of the financial markets (i.e., persistency in the exchange rate). The Czech Republic is not particularly flexible, but the persistence is offset by a steep Phillips curve and

Table 2

The main coefficients used in country-specific models

\begin{tabular}{llllll}
\hline & $\begin{array}{l}\text { Output } \\
\text { persistence } \\
\left(a_{1}\right)\end{array}$ & $\begin{array}{l}\text { Expectations } \\
\text { formation }\left(b_{2}\right)\end{array}$ & $\begin{array}{l}\text { The slope of } \\
\text { the supply } \\
\text { curve }(\gamma)\end{array}$ & $\begin{array}{l}\text { Exchange } \\
\text { rate persistence } \\
\left(c_{1}\right)\end{array}$ & $\begin{array}{l}\text { Taylor rule } \\
\text { policy persistence } \\
\left(d_{1}\right)\end{array}$ \\
\hline EU-15 countries & & & & 0.90 & 0.40 \\
Greece & 0.60 & 0.40 & 0.20 & 0.30 & 0.40 \\
Ireland & 0.80 & 0.70 & 0.20 & 0.40 & 0.50 \\
Italy & 0.90 & 0.60 & 0.05 & 0.50 & 0.60 \\
Spain & 0.90 & 0.90 & 0.10 & & 0.50 \\
New member countries & & & & 0.20 & 0.40 \\
The Czech Republic & 0.80 & 0.50 & 0.20 & 0.50 & 0.50 \\
Hungary & 0.90 & 0.50 & 0.05 & 0.50 & 0.50 \\
Poland & 0.90 & 0.80 & 0.30 & 0.90 & 0.90 \\
Slovakia & 0.90 & 0.50 & 0.10 & & \\
Slovenia & 0.90 & 0.70 & 0.20 & & \\
\hline Source. Varioun & & & & \\
\hline
\end{tabular}

Source. Various publications and authors' simulations. 
largely forward-looking financial markets. Hungary has the least favorable monetary policy environment in our sample. A flat Phillips curve is accompanied by mostly backward-looking element in the exchange rate behavior. Moreover, the latter is buttressed by sluggish monetary policy reactions. Poland has a quick direct exchange rate channel, which is supplemented, with a lag, by the traditional output gap channel. This yields the specific "two-peak" response of inflation to a monetary policy shock reported in the literature. Slovakia exhibits mostly backward-looking behavior in the financial markets and monetary policy reactions are sluggish. Such persistency is only partially compensated by the Phillips curve, the steepness of which is below the sample average. Slovenia displays similar traits of backward-looking behavior in the financial markets and sluggish monetary policy reactions. However, Slovenia's Phillips curve is steep, diminishing the cost of disinflation.

\subsection{Simulations}

Basing calibrations on observed past behavior makes our results open to the Lucas critique since we are asking what the optimal disinflation strategy is, conditional on the past structure of the economy and historically observed agents' response to shocks. There is no a priori reason why the model coefficients should remain fixed during the whole disinflation period, especially if the disinflation strategy is supplemented by structural reforms (Ciccarelli and Rebucci, 2006). ${ }^{10}$ Reform laggards are likely to benefit from the progressive adoption of EU laws and regulations (acquis communautaire). Thus, we may overestimate the sacrifice ratio if the country reforms during the disinflation period or if the agents become more forward-looking. By ignoring longrun processes, such as the Balassa-Samuelson effect, we may underestimate convergence-related inflation. In general, however, we find the past-structure, short-run scenario quite attractive, because it provides the benchmark against which scenarios of changing policy environment would compare.

In our first set of simulations - "what output gap would have been consistent with bringing inflation toward the Maastricht criterion?" - the monetary authority announces a lower (credible) inflation target equivalent to the Maastricht inflation criterion. The announcement specifies the target only, letting the authorities choose a disinflation path consistent with the lowest possible costs, given its reaction function. The magnitude of the disinflation announcement depends on inflation observed at the time of the announcement and the value of the Maastricht criterion at that time. ${ }^{11}$

The starting point of our simulations is based on the assumption of a typical transmission period: disinflations in our simulations start six quarters before the particular country has had inflation at or below the criterion for the last time. In countries that have yet to meet the criterionHungary, Slovakia, and Slovenia - the disinflation starts six quarters before the end of our data sample; the same rule is applied for Greece, which did not have inflation at the criterion during 2001-2005. The 5-year disinflation trajectories and associated cumulative output gaps are thus fully model-depended (Fig. 3 and Appendix A).

While disinflation costs in term of lost output are relatively low for the EU-15 countries, given that their required disinflation was only 90 basis points on average, they are much larger for such high-inflation NMCs as Hungary or Slovakia. For example, Ireland's disinflation of 170 basis

\footnotetext{
${ }^{10}$ It is only the impact of structural reforms on the market structure, and thus on the structural parameters, that is open to the Lucas critique, as expectations are model-consistent.

${ }^{11}$ We exclude Italy, which had inflation below the criterion thanks to substantial output gap.
} 
Greece

Disinflation from 3.2 percent to 2.6 percent
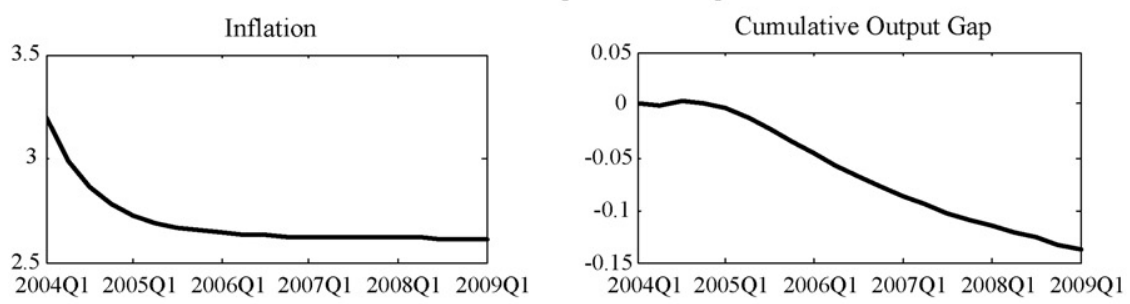

Ireland

Disinflation from 4.6 percent to 2.9 percent
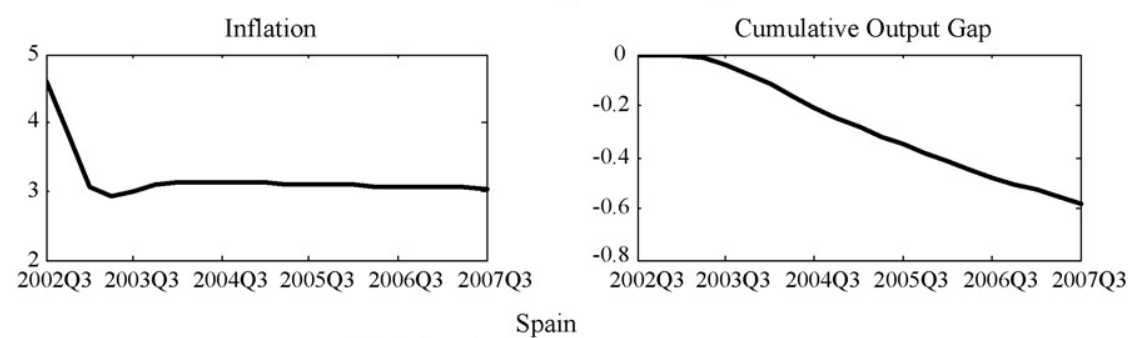

Disinflation from 3.0 percent to 2.6 percent

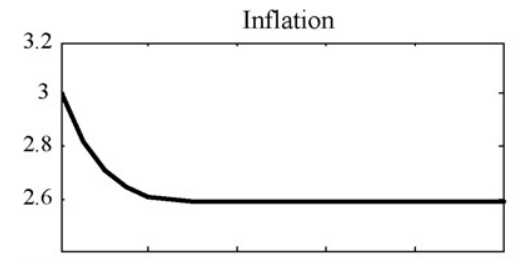

2004Q1 2005Q1 2006Q1 2007Q1 2008Q1 2009Q1

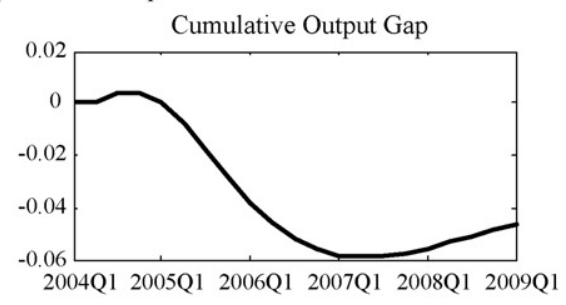

The Czech Republic

Disinflation from 3.9 percent to 2.7 percent
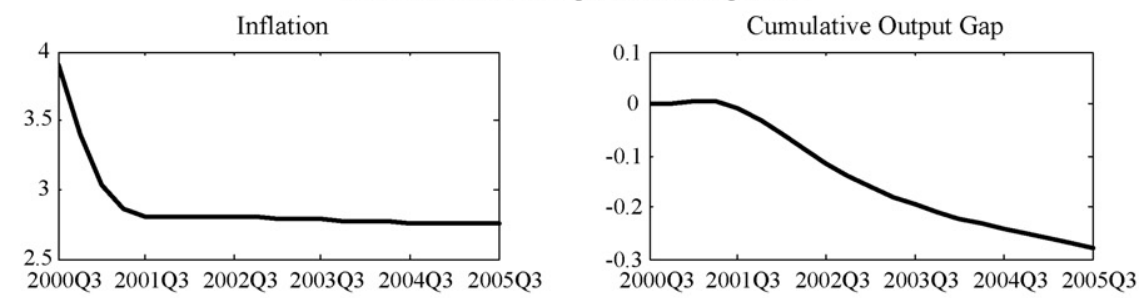

Hungary

Disinflation from 5.5 percent to 2.6 percent
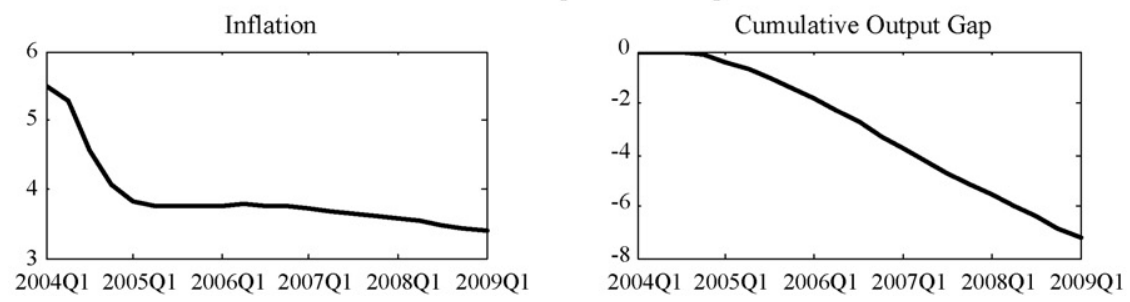

Fig. 3. The disinflation path and cumulative output gap (in \%). 
Poland

Disinflation from 3.1 percent to 2.0 percent
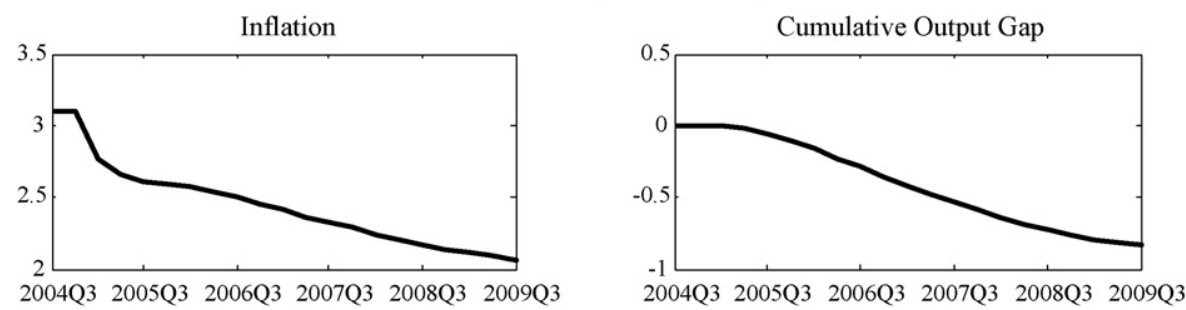

Slovakia

Disinflation from 8.6 percent to 2.7 percent
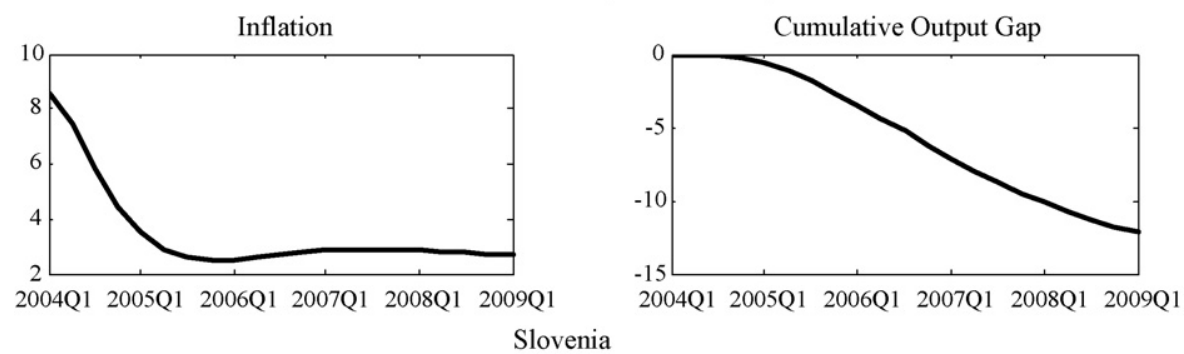

Disinflation from 5.2 percent to 2.7 percent
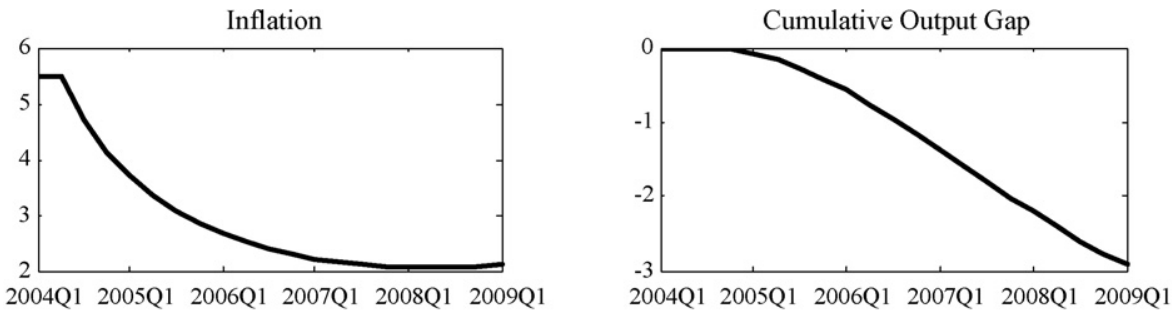

Source: Authors' calculations.

Fig. 3. (Continued).

points would require sacrificing only about $0.5 \%$ of GDP during the next 5 years. In contrast, disinflations of 300 basis points and 600 basis points in Hungary and Slovakia would require sacrificing a whopping $7 \%$ and $12 \%$ of GDP, respectively. These results reflect a much less effective transmission mechanism in the two countries, but it is hard to imagine that the national central banks could either justify such a disinflation strategy or that their policies would not become more credible in due course. In contrast, the three remaining NMCs show relatively small output losses: $0.75 \%$ of GDP in the Czech Republic and Poland and 3\% in Slovenia.

In our second set of simulations we normalize the disinflation shock to 100 basis points for all countries, thus avoiding the complication of different initial disinflation announcements. Following Cecchetti and Ehrmann (1999), we cumulate the associated output gap both over the 3year horizon and full simulation horizon (Table 3). While our model does not allow calculation of confidence intervals, our simulation results are similar to structural-model estimates of the sacrifice ratio (see Bulî́r and Hurník, 2006). 
Table 3

The sacrifice ratios in a 100-basis point disinflation (in\% of GDP)

\begin{tabular}{|c|c|c|c|c|c|c|c|c|c|}
\hline \multicolumn{5}{|c|}{ EU-15 countries } & \multicolumn{5}{|c|}{ New member countries } \\
\hline $\begin{array}{l}\text { Cumulative } \\
\text { output gap }\end{array}$ & Greece & Ireland & Italy & Spain & $\begin{array}{l}\text { The Czech } \\
\text { Republic }\end{array}$ & Hungary & Poland & Slovakia & Slovenia \\
\hline 12-Quarter & -0.1 & -0.1 & -0.5 & -0.25 & -0.1 & -0.75 & -0.5 & -0.75 & -0.3 \\
\hline Full-horizon & -0.75 & -0.5 & -3.5 & -1.75 & -0.5 & -4 & -0.75 & -0.75 & -1.3 \\
\hline
\end{tabular}

Source. Authors' simulations.

Output losses differ across countries and across simulation horizons, conditional on the stability of simulation coefficients. First, across countries, disinflation does not seem very costly in the Czech Republic, Ireland, and Poland, whereas the costs appear very high in Hungary and Italy and only marginally smaller in Slovenia and Spain. Second, across time horizons, while the 3-year and full-horizon output losses are quite similar in the Czech Republic, Ireland, Poland, or Slovakia, the long-run losses are a multiple of the short-run losses in Greece, Hungary, Italy, Slovenia, and Spain. These differences can be attributed to the speed of the exchange rate passthrough as well as to the interest rate sensitivity of the exchange rate. In some countries, such as Hungary and Poland, the direct exchange rate channel helps initially to decrease inflation relatively quickly; however, further disinflation remains costly when this channel is exhausted. Thus, the point about passing through purgatory on the way to the euro may have some validity after all (Buiter, 2004).

While the magnitude of output losses is mostly persistency-related, this persistency cannot be solely attributed to the structural characteristics of the individual economies. The unemployment-inflation trade-off changes over time depend on monetary policy credibility (Laxton and N'Diaye, 2002). Thus, the large output losses in Hungary can be attributed to the limited credibility of national monetary policy, which has not been able to bring inflation systematically below 5\% since 1990, and has disinflated from double-digits only in 2001, some 5 years later than in the Baltics or the Czech Republic. A similar argument can be made for Slovakia and Slovenia. In the eurozone countries, however, given the existence of a common monetary policy, the results should be attributable fully to the structural characteristics of the respective economies.

Our results for the selected EU-15 countries, most notably Italy and Spain, seem to be consistent with the policy choice of "low inflation now, reforms later." On the one hand, their short-term costs of disinflation are relatively modest, mainly because of "borrowed credibility" from the ECB. On the other hand, their long-term costs are high, reflecting structural rigidities inherited from the past. In their rush to the euro, these countries set aside reforms that would ultimately have left their economies more flexible and better prepared for future disinflations. In contrast, Ireland's economy seems more flexible and disinflations ought to be relatively painless over the long run.

\section{Policy implications}

The policy relevance of the Maastricht inflation criterion has been unfairly downplayed. The criterion has had a profoundly positive impact on the public stance toward inflation and a less positive impact on the choice of instruments to achieve the desired inflation outcome in the run- 
up to the euro. EU member country authorities have known that inflation can be brought down either by short-term, fiat measures or by long-term, market-oriented reforms, or by a combination of both. While the former instruments are virtually costless in terms of domestic political capital, the latter can be costly, especially in economies with longstanding rigidities supported by influential political groups.

The choice between fiat and reform disinflation strategies is affected by the definition of the Maastricht inflation criterion. A tight definition of the criterion may tilt the NMCs toward the fiatmeasure strategy as the chance of meeting a tight target may seem limited without aggressive fiat measures. A softer criterion, in contrast, would make the long-run reform strategy more likely to succeed and, thus, more likely to be selected by the authorities. The fiat strategy may seem particularly attractive to countries that expect to benefit immediately from the euro, or that assign a high discount factor to the future because, for example, the leading political party faces reelection. Short-term benefits of the euro would come either from lower fiscal borrowing costs (Greece and Italy), reduced current account vulnerability (the Baltics), or from the ECB lowinflation credibility (Italy, Hungary, and Slovakia). The benefits of lower interest rates, however, are not relevant for most NMCs - their public-debt-to-GDP ratios are one-half or less compared with those of Greece and Italy in the 1990s.

The choice of whether to reform or not affects, however, both future inflation and the cost of future disinflations. On the one hand, regulated markets with high markups and labor costs generate inflationary impulses. On the other hand, economies with nominal rigidities tend to have inefficient monetary transmission mechanisms, and inflationary impulses need to be extinguished with larger output gaps. Although a country opting not to reform may succeed in lowering inflation temporarily, it will fail to address the underlying cost-push factors. Moreover, its sacrifice ratio would remain high, making future disinflations costly. Still, some countries may be better off by opting for the fiat measures, especially if the ECB credibility makes agents more forward looking. ${ }^{12}$

A rush toward low inflation would be costly both for the NMCs and the ECB. It is not clear that all of the NMCs need (or would gain) monetary policy credibility. Moreover, even if such credibility gains would be achieved in Hungary or Slovakia, would it be worth the output losses implied by our simulations? The long-term risks associated with a premature and fiat-driven entry into the eurozone are similar to those faced by some old member countries-stalled reforms, inflexible economies, and real exchange rate appreciation following the euro adoption. The long-term impact on the ECB can be costly as well. The tighter the Maastricht inflation criterion, the more NMCs will choose the fiat measures, postponing structural reforms and worsening the eurozone transmission mechanism, with an adverse impact on ECB decision making.

Building on the above results, we draw two implications for the Maastricht inflation criterion. First, inclusion of economies with large negative output gaps in the three best performers has made the inflation criterion unnecessarily tight, providing incentives for fiat disinflation measures. It would seem preferable to exclude countries with negative gaps from the calculation, or to calculate the average inflation rate over the full length of the business cycle. This could be a relatively undemanding change - the estimates of the output gap are published regularly by the EU (the AMECO database). Second, the short, 12-month testing period during the ERM2 period

\footnotetext{
${ }^{12}$ Greece provides an example of an improved transmission mechanism despite modest reforms and mostly fiat-driven disinflation (Chionis and Leon, 2006).
} 
may further stimulate the NMCs to use the fiat strategy. A longer testing period, covering the full business cycle, would seem more appropriate.

\section{Conclusions}

The Maastricht inflation criterion has been an influential nominal rule for the past 15 years. It has helped reduce inflation dispersion among the EU countries to levels last seen in the 1960s, even though it could not prevent a gradual increase in inflation in some countries in the 2000s. While the criterion influences positively the public stance toward low inflation, it biases the choice of the disinflation strategy toward fiat measures in countries that have a lot to gain from the euro. These countries tend to opt for "low inflation now, reforms later," which yields low inflation instantly at the cost of postponing structural reforms and preserving comparatively high sacrifice ratios. While the purgatory of the ERM2 can be made relatively painless by fiat measures, such a strategy is likely to result in inefficient transmission mechanisms and costly disinflations, complicating ECB decision making.

The main contribution of the paper is finding empirical support for the link between the choice of disinflation strategies and disinflation costs. While disinflation does not seem very costly in countries that tend to be labeled as reformist, say, the Czech Republic or Ireland, the costs appear much higher in reform laggards, say, Hungary or Italy. To this end, we formulate a simple macroeconomic model, calibrate it using the available empirical results for the Czech Republic, Greece, Hungary, Ireland, Italy, Poland, Slovakia, Slovenia, and Spain, and simulate the output consequences of disinflation strategies. We find that - using past performance and assuming stability of our coefficients - the implied sacrifice ratios differ across countries and across the simulation horizons. These differences stem from the slope of national Phillips curves, the expectations formation, and the level of output, inflation, and exchange rate persistence.

Our results suggest two potential changes to the definition of the Maastricht inflation criterion. First, calculate it so as to avoid the influence of the business cycle, which periodically makes the criterion very tight. Second, lengthen the period for the criterion evaluation to avoid reliance on fiat disinflation strategies.

\section{Acknowledgements}

The paper was mostly written when Jaromír Hurník was visiting the IMF Institute. The authors are thankful for comments from A. Carare, L. Christiano, M. Čihák, E. Detragiache, M. Hampl, V. Koen, L. Lipschitz, M. Mandel, O. Schneider, and two anonymous referees; they also benefited from seminars at the Czech National Bank and the International Monetary Fund.

\section{Appendix A. The model}

This appendix details the model specifications and individual country calibrations. The model specification takes the form ${ }^{13}$ :

\footnotetext{
${ }^{13}$ The model was simulated in MATLAB, using the IRIS computing environment. Further details are available on request.
} 
Table A.1

Model variables

\begin{tabular}{ll}
\hline$y_{t}$ & The deviation of the log output from its steady state level \\
$r_{t}$ & The deviation of the long-term real interest rate from its steady state level \\
$q_{t}$ & The deviation of the real exchange rate from its steady state level \\
$\pi_{t}$ & Inflation, quarter-to-quarter change of the price level \\
$E_{t} \pi_{t+1}$ & Inflation expectations \\
$\pi_{t+1}^{e}$ & Model consistent inflation expectations \\
$\pi_{t}^{i m p}$ & The rate of growth of import prices \\
$\Delta s_{t}$ & The change in the nominal exchange rate \\
$i_{t}$ & The short-term (3-month) nominal interest rate (the policy rate) \\
$i r_{t}$ & The long-term nominal interest rate \\
$\pi_{t}^{*}$ & Foreign inflation \\
$i r_{t}^{*}$ & The foreign long-term nominal interest rate \\
\hline
\end{tabular}

$$
\begin{aligned}
& y_{t}=a_{1} y_{t-1}-a_{2} r_{t-1}+a_{3} q_{t-1}+\mu_{t} \\
& \pi_{t}=b_{1}\left(b_{2} \pi_{t-1}+\left(1-b_{2}\right) E_{t} \pi_{t+1}\right)+\left(1-b_{1}\right) \pi_{t-1}^{\mathrm{imp}}+\gamma y_{t-1}+\eta_{t} \\
& \pi_{t}^{\mathrm{imp}}=m_{1} \pi_{t-1}^{\mathrm{imp}}+\left(1-m_{1}\right)\left(\pi_{t-1}^{*}+\Delta s_{t-1}\right) \\
& E_{t} \pi_{t+1}=e_{1} \pi_{t+1}^{e}+\left(1-e_{1}\right) \pi_{t-1} \\
& \Delta s_{t+1}=c_{1} \Delta s_{t}+\left(1-c_{1}\right)\left(i r_{t}-i r_{t}^{*}-\operatorname{prem}_{t}\right)+v_{t} \\
& i_{t}=d_{1} i_{t-1}+\left(1-d_{1}\right)\left(\pi_{t+1}^{e}+d_{2}\left(\pi_{t+1}^{e}-\pi^{\mathrm{T}}\right)+d_{3} y_{t}\right)+\varepsilon_{t} \\
& i r_{t}=f_{1} i r_{t-1}+\left(1-f_{1}\right)\left[\frac{i_{t}+i_{t+1}+i_{t+2}+i_{t+3}}{4}\right] \\
& r_{t}=i r_{t}-E_{t} \pi_{t+1} \\
& q_{t}=q_{t-1}+\frac{\Delta s_{t}+\pi_{t}^{*}-\pi_{t}}{4}
\end{aligned}
$$

Table A.2

Parameter calibrations

\begin{tabular}{llllllllll}
\hline Parameters & Greece & Ireland & Italy & Spain & The Czech Republic & Hungary & Poland & Slovakia & Slovenia \\
\hline$a_{1}$ & 0.6 & 0.8 & 0.9 & 0.9 & 0.8 & 0.9 & 0.9 & 0.9 & 0.9 \\
$a_{2}$ & 0.2 & 0.1 & 0.2 & 0.3 & 0.25 & 0.05 & 0.1 & 0.1 & 0.1 \\
$a_{3}$ & 0.1 & 0.1 & 0.1 & 0.1 & 0.1 & 0.1 & 0.1 & 0.1 & 0.1 \\
$b_{1}$ & 0.9 & 0.6 & 0.9 & 0.9 & 0.8 & 0.8 & 0.8 & 0.8 & 0.7 \\
$b_{2}$ & 0.4 & 0.7 & 0.6 & 0.9 & 0.5 & 0.5 & 0.8 & 0.5 & 0.7 \\
$\gamma$ & 0.2 & 0.2 & 0.05 & 0.1 & 0.2 & 0.05 & 0.3 & 0.1 & 0.2 \\
$m_{1}$ & 0.6 & 0.4 & 0.7 & 0.6 & 0.6 & 0.3 & 0.0 & 0.6 & 0.0 \\
$e_{1}$ & 0.9 & 0.9 & 0.9 & 0.9 & 0.9 & 0.9 & 0.9 & 0.9 & 0.9 \\
$c_{1}$ & 0.9 & 0.3 & 0.4 & 0.5 & 0.2 & 0.5 & 0.5 & 0.7 & 0.9 \\
$d_{1}$ & 0.4 & 0.4 & 0.5 & 0.6 & 0.5 & 0.9 & 0.4 & 0.9 & 0.5 \\
$d_{2}$ & 0.5 & 0.5 & 0.5 & 0.5 & 0.5 & 0.5 & 0.5 & 0.5 & 0.5 \\
$d_{3}$ & 0.5 & 0.5 & 0.5 & 0.5 & 0.5 & 0.5 & 0.5 & 0.5 & 0.5 \\
$f_{1}$ & 0.5 & 0.5 & 0.5 & 0.5 & 0.5 & 0.5 & 0.5 & 0.5 & 0.5 \\
\hline
\end{tabular}


where Eqs. (A.1)-(A.9) represent aggregate demand, aggregate supply, import price formation, inflation expectations formation, uncovered interest rate parity, policy reaction function, interest rate term structure, Fisher equation, and real exchange rate formation, respectively. Tables A.1 and A.2 define the model variables and detail the country-specific calibrations. The values of the steady-state variables are normalized to zero and so are the foreign inflation and interest rates. It follows that the steady-state level of domestic nominal interest rate equals inflation (steady-state level of real interest rate is equal to zero) and the same holds for the steady-state level of the nominal exchange rate change. The latter simply equals the difference between domestic and foreign inflation.

\section{References}

Ahearne, A., Pisani-Ferry, J., 2006. The Euro: only for the agile. Bruegel Policy Brief 2006/01, Brussels. Available at: http://www.bruegel.org/doc_pdf_291.

Alberola-Ila, E., Tyrväinen, T., 1998. Is there scope for inflation differentials in EMU? An empirical evaluation of the Balassa-Samuelson model in EMU countries. Bank of Finland Discussion Papers 15/98, Helsinki.

Angeloni, I., Ehrmann, M., 2004. Euro area inflation differentials. ECB Working Paper 388, Frankfurt. Available at: http:// www.ecb.int/pub/pdf/scpwps/ecbwp388.pdf.

Arestis, P., Mouratidis, K., 2004. Is there a trade-off between inflation variability and output-gap variability in the EMU countries? NIESR Discussion Paper 238, London. Available at: http://www.niesr.ac.uk/pubs/dps/dp238.pdf.

Babetskii, I., Boone, L., Maurel, M., 2004. Exchange rate regimes and shocks asymmetry: The case of the accession countries. J. Comp. Econ. 32, 212-229.

Bárta, V., 2006. Fulfillment of the Maastricht inflation criterion by the Czech Republic: potential costs and policy options. CNB Research and Policy Note 4, Prague. Available at: http://www.cnb.cz/www.cnb.cz/en/research/research_publications/irpn/2005/irpn_4_2005.html.

Batini, N., Haldane, A., 1999. Forward-looking rules for monetary policy. In: Taylor, J.B. (Ed.), Monetary Policy Rules. University of Chicago Press, Chicago, pp. 157-192.

Beggs, J., 2000. ECB looks to Irish government to tackle inflation. Allied Irish Banks Global Treasury Economic Research, Dublin. Available at: http://www.johnbeggs.com/jb/comment.asp?0404200033.

Berg, A., Karam, P., Laxton, D., 2006. A practical model-based approach to monetary policy analysis-overview. IMF Working Paper 06/81, Washington, DC. Available at: http://www.imf.org/external/pubs/ft/wp/2006/wp0681.pdf.

Bini Smaghi, L., 1994. EMS discipline: did it contribute to inflation convergence? Banca Nazionale Lavoro Quart. Rev. 47, 187-197.

Buiter, W.H., 2004. To purgatory and beyond: when and how should the accession countries from Central and Eastern Europe become full members of EMU? CEPR Discussion Paper 4342, London.

Bulîr, A., Šmídková, K., 2005. Exchange rates in the new EU accession countries: what have we learned from the forerunners? Econ. Syst. 29, 163-186.

Bulîr, A., Hurník, J., 2006. The Maastricht inflation criterion: how unpleasant is purgatory? IMF Working Paper 06/154, Washington, DC. Available at: http://www.imf.org/external/pubs/ft/wp/2006/wp06154.pdf.

Camarero, M., Esteve, V., Tamarit, C., 2000. Price convergence of peripheral European countries on the way to the EMU: a time series approach. Empirical Econ. 25, 149-168.

Cecchetti, S., Ehrmann, M., 1999. Does inflation targeting increase output volatility? An International comparison of policymakers' preferences and outcomes. NBER Working Paper Series 7426, Cambridge, MA. Available at: http:// www.nber.org/papers/w7426.

Chionis, D.P., Leon, C.A., 2006. Interest rate transmission in Greece: did EMU cause a structural break? J. Policy Model. 28, 453-466.

Ciccarelli, M., Rebucci, A., 2006. Has the transmission mechanism of European monetary policy changed in the run-up to EMU? Eur. Econ. Rev. 50, 737-776.

Coats, W., Laxton, D., Rose, D. (Eds.), 2003. The Czech National Bank's forecasting and policy analysis system. The Czech National Bank, Prague.

Conway, P., Janod, V., Nicoletti, G., 2005. Product market regulation in OECD countries: 1998-2003. OECD Economics Department Working Paper WKP(2005)6, Paris. Available at: http://www.olis.oecd.org/olis/2005doc.nsf/ 43bb6130e5e86e5fc12569fa005d004c/72b2dfdd81a241c5c1256fab008278e5/\$FILE/JT00181518.DOC. 
Čihák, M., Holub, T., 2005. Price convergence in EU-accession countries: evidence from the International comparison. Économie Internationale, 2e trimestre, 102, 61-84.

Égert, B., Drine, I., Lommatzsch, K., Rault, C., 2005. The Balassa-Samuelson effect in Central and Eastern Europe: Myth or reality? EPEE Working Paper 05-15, Evry. Available at: http://www.univ-evry.fr/PagesHtml/laboratoires/Epee/ EPEE/documents/wp/05-15.pdf.

European Commission, 2004. Convergence report 2004-technical annex. A commission services working paper, SEC 1268, EC, Brussels. Available at: http://europa.eu.int/comm/economy_finance/publications/european_economy/ 2004/cr2004annex_en.pdf.

European Trade Union Confederation, 2006. ETUC calls on euro area finance ministers to end the 'cycle of madness' so as to protect the recovery in the European economy. Economic, monetary and fiscal policies press release, March 12, European Trade Union Confederation, Brussels. Available at: http://www.etuc.org/a/2180.

Flek, V., Marková, L., Podpiera, J., 2003. Sectoral productivity and real exchange rate appreciation: much ado about nothing? Finance a úvěr/Czech J. Econ. Finance 53, 130-153.

Fuhrer, J., Moore, G., 1995a. Inflation persistence. Quart. J. Econ. 110, 127-159.

Fuhrer, J., Moore, G., 1995b. Monetary policy trade-offs and the correlation between nominal interest rates and real output. Am. Econ. Rev. 85, 219-239.

Fuhrer, J., 1997. Inflation/output variance trade-offs and optimal monetary policy. J. Money Credit Bank. 29, 214-234.

Hofmann, B., Remsperger, H., 2005. Inflation differentials among the Euro area countries: potential causes and consequence. J. Asian Econ. 16, 403-419.

Koen, V., van den Noord, P., 2005. Fiscal gimmickry in Europe: one-off measures and creative accounting. OECD Economics Department Working Papers 417, Paris. Available at: http://www.olis.oecd.org/olis/2005doc.nsf/linkto/ eco-wkp(2005)4.

Laxton, D., N'Diaye, P. M'B. P., 2002. Monetary policy credibility and the unemployment-inflation tradeoff: some evidence from 17 industrial countries. IMF Working Paper 02/220, Washington, DC. Available at: http://www.imf.org/external/pubs/ft/wp/2002/wp02220.pdf.

Organisation for Economic Co-operation Development, 2002. Inflation persistence in the Euro area. OECD Econ. Outlook 72, 163-171.

Ozkan, F.G., Sibert, A., Sutherland, A., 2004. Monetary Union and the Maastricht inflation criterion: the accession countries. Economics of Transition 12, 635-52. Available at: http://www.blackwell-synergy.com/doi/pdf/10.1111/ j.0967-0750.2004.00197.x.

Rotemberg, J.J., Woodford, M., 1997. An optimization-based econometric framework for the evaluation of monetary policy. In: Rotemberg, J.J., Bernanke, B.S. (Eds.), NBER Macroeconomics Annual 1997. MIT Press, Cambridge and London, pp. 297-346.

Rumler, F., 2005. Estimates of the open economy new Keynesian Phillips curve for euro area. ECB Working Paper 496, Frankfurt. Available at: http://www.ecb.int/pub/pdf/scpwps/ecbwp496.pdf.

Schadler, S., Drummond, P., Kuijs, L., Murgasova, Z., van Elkan, R., 2005. Adopting the euro in Central EuropeChallenges of the next step in European integration. IMF Occasional Paper 234, Washington, DC.

Slovak National Bank, 2005. Medium-term forecast. Slovak National Bank, Bratislava. Available at: http://www.nbs.sk/ MPOL/PREDIK/2005-2A.PDF.

Svensson, L.E.O., 2000. The first year of the Eurosystem: inflation targeting or not? Am. Econ. Rev. 90, 95-99.

Taylor, J.B., 1993. Discretion versus policy rules in practice. In: Carnegie-Rochester Conference Series on Public Policy, vol. 39. pp. 195-220.

Walsh, C., 2003. Monetary Economics: Theory and Policy. MIT Press, Cambridge, MA. 